\title{
PERAN PEKERJA SOSIAL DALAM DUNIA INDUSTRI DI INDONESIA
}

\author{
Oleh: \\ Derin Darachita Pradini, Dessy Hasanah Siti A., \& Maulana Irfan
}

Email:

(derindp@gmail.com; dessyhasanahsitiasiah@yahoo.com; sangirfan@gmail.com)

\begin{abstract}
ABSTRAK
Artikel ini berjudul "Peran Pekerja Sosial dalam Dunia Industri di Indonesia". Sebagai negara berkembang yang tidak luput dari arus globalisasi dan industrialisasi, kebutuhan akan Pekerja Sosial khususnya di dunia industri di Indonesia pun semakin terasa. Hanya saja kesadaran akan kebutuhan Pekerja Sosial dalam bidang industri di Indonesia masih minim. Dalam artikel ini, penulis berupaya menjabarkan andil Pekerja Sosial industri dalam memanusiawikan dunia kerja di Indonesia akibat dari industrialisasi. Diantaranya dengan cara memberikan pelayanan yang menangani kesejahteraan, kesehatan dan keselamatan kerja, relasi buruh dan majikan, atau perekrutan dan pengembangan pegawai serta melakukan pemberdayaan masyarakat dan tanggung jawab sosial lainnya terhadap masyarakat. Dalam praktiknya di perusahaan, pelayanan yang diberikan Pekerja Sosial industri di antaranya adalah bagian Employee Assistance Programs (EAPs), Human Resources Development (HRD), Coorporate Social Responsibility (CSR), Kesehatan dan Keselamatan Kerja (K3), serta kebijakan dan advokasi. Dilihat dari permasalahan sosial yang diakibatkan dunia industry, banyak peran Pekerja Sosial di Indonesia yang dapat dijalankan, hanya saja kesadaran perusahaan dan stakeholder terkait yang berada dalam duni industry belum paham betul dan sadar akan kebutuhan Pekerja Sosial industry di Indonesia. Oleh karena itu diperlukan lebih banyak penyebaran informasi dan juga bukti nyata dari praktik Pekerja Sosial industry. Perlu lebih banyak lagi sosialisasi dan penyajian data pasti mengenai Pekerja Sosial, seperti dengan mengesahkan RUU mengenai Pekerja Sosial sebagai payung hukum sehingga posisi Pekerja Sosial di Indonesia menjadi lebih diakui dan jelas bidang intervensinya, khusunya Pekerja Sosial industri.
\end{abstract}

Kata Kunci: Peran Pekerja Sosial Industri, Akibat Industrialisasi, Pelayanan Pekerjaan Sosial Industri

\begin{abstract}
This article titled "The Role of Social Worker in The Industry in Indonesia". As a developing country that can't escape from globalization and industrialization, the need for Social Worker, especially in the industrialized world in Indonesia was increasingly felt. However, awareness of the need for Social Worker in the field of industry in Indonesia is still lacking. In this article, author try to describe the role of Social Worker in humanizing the industrial world in Indonesia which is caused by industrialization. By providing services that deal with welfare, health and safety, labor relations with the employer, or recruitment and employee development and community empowerment, and also social responsibility towards the community. In the corporate, the services that provide by Occupational Social Work are Employee Assistance Programs (EAPS), Human Resources Development (HRD), Corporate Social Responsibility (CSR), Occupational Health and Safety (K3), and policy and advocacy. Based on the social problems caused by industry, many roles that can Social Worker do. However, corporate and mutual stakeholder awareness about the needs of
\end{abstract}


occupationa; Social work still not enough to make it come true. Need more information and real action that Social Worker present. Need more socialization and factual data about occupational Social Worker in Indonesia, like by authorize the RUU about Social Worker that can be legal protection, so that the role and field of intervention of Social Worker, especially occupational Social Worker, can be recognized.

Keywords: Role of Occupational Social Work, Caused of Industrialization, Services of Occupational Social Work

\section{Pendahuluan}

Industrialisasi dan globalisasi merupakan dua hal yang saling berkaitan yang memiliki pengaruh satu sama lain. Karena pada dasarnya kedua hal tersebut merupakan bagian dari proses modernisasi yang dipengaruhi oleh semakin maju dan canggihnya teknologi. Salah satu efek dari globalisasi dan industrialisasi adalah keadaan masyarakat yang semakin berkembang sehingga menyebabkan perubahan yang mempengaruhi kondisi social masyarakat. Berkembangnya kondisi social masyarakat otomatis menyebabkan permasalahan sosial yang ada berkembang pula. Isu-isu social yang ada menjadi semakin kompleks, oleh sebab itu dibutuhkan penyelesaian yang memiliki efek berkelanjutan atau setidaknya dapat meminimalisir efek dari permasalahan social tersebut dengan meningkatkan keberfungsian social masyarakat. Disinilah peluang Pekerja Sosial untuk turut memiliki andil dalam menangani masalah sosial yang ada diantaranya dalam bidang yang terkait dengan hasil globalisasi dan industrialisasi, yakni dunia industri sebagai Pekerja Sosial industri (industrial social worker) atau Pekerja Sosial di perusahaan (occupational social work).

Sebagai negara berkembang yang tidak luput dari arus globalisasi dan industrialisasi, kebutuhan akan Pekerja Sosial di Indonesia pun semakin terasa. Hanya saja kesadaran dunia industri di Indonesia akan kebutuhan dari peran Pekerja Sosial industri masih minim. Padahal jika dilihat dari sejarahnya, Pekerja Sosial yang khusus menangani bidang industry ini hadir sejak tahun 1920an di Eropa. Berarti sudah hanpir satu abad salah satu bidang garapan Pekerja Sosial ini ada.

Di Indonesia, seperti yang dilansir dari situs resmi Dinas Sosial Provinsi Jawa Barat, saat ini kebutuhan tenaga profesional di bidang pekerjaan sosial masih sangat besar mengingat estimasi jumlah Penyandang Masalah Kesejahteraan Sosial (PMKS) tahun 2013 sekitar 15,5 juta rumah tangga, sedangkan jumlah Pekerja Sosial yang baru sekitar 15.522 orang. Jika ratio ideal misalnya 1 Pekerja Sosial menangani 100 rumah tangga, maka masih dibutuhkan kurang lebih 139.000 orang Pekerja Sosial. Begitu pula dibutuhkan pekerja sosial medis di rumah sakit, Pekerja

Sosial industri, Pekerja Sosial forensik di Lapas/Bapas, Pekerja Sosial Klinis di lembaga-lembaga rehabilitasi sosial, korban penyalahgunaan Napza, Pekerja Sosial spesialis perlindungan anak, Pekerja Sosial spesialis manajemen bencana dan sebagainya. Sayangnya di Indonesia belum ada data pasti mengenai jumlah Peksos Industri yang ada.

Seperti halnya Pekerja Sosial medik (medical social worker) yang bekerja di rumah sakit, para Pekerja Sosial industri (industrial social worker) ini bekerja di perusahaan-perusahaan, baik negeri maupun swasta, untuk menangani kesejahteraan, kesehatan dan keselamatan kerja, relasi buruh dan majikan, atau perekrutan dan pengembangan pegawai. (lihat Friedlander dan Thackeray, 1982; Payne, 1991; Johnson, 1984; DuBois dan Miley, 1992; Suharto, 1997).

Dari uraian di atas, jelas sekali bahwa peran Pekerja Sosial industri bukan hanya meliputi kesejahteraan, keselamatan, kesehatan, serta pengembangan dan pelatihan pemilik kepentingan di perusahaan ataupun karyawannya saja, melainkan seluruh aspek yang terlibat dan menjadi bagian dari perusahaan. Seperti masyarakat sekitar tempat perusahaan berdiri, ataupun masyarakat secara lebih luas lagi yang salah satunya dituangkan perusahaan dalam bentuk program sebagai wujud dari tanggung jawab perusahaan terhadap masyarakat yang dikenal dengan Coorporate Social Responsibility (CSR) atau Tanggung Jawab Sosial Perusahaan. 


\section{Akibat Industrialisasi}

Fenomena industrialisasi melahirkan mekanisasi dan otomatisasi yang menggeser pekerjaan manusia dengan alat dan mesin sehingga membuat tenaga dari para pekerja seperti tidak penting. Sebagai contoh, sekarang sudah hampir seluruh pintu masuk jalan tol di Indonesia menggunakan sensor otomatis pendeteksi kendaraan yang hendak masuk ke jalan tol sehingga tidak lagi membutuhkan operator (manusia). Dengan digunakannya mesin ini, lapangan pekerjaan pada perusahaan jasa yang mengurus jalan tol ini menjadi berkurang, karena perusahaan menganggap bahwa penggunaan mesin tersebut jauh lebih efisien disbanding menggunakan jasa manusia. Dan bisa jadi di tahun-tahun yang akan datang, seluruh operator yang bertugas di pintu masuk ataupun pintu keluar tol akan digantikan semuanya oleh mesin. Hal inilah yang kemudian menyebabkan rasa tidak berdaya pada diri pekerja yang tidak hanya berdampak pada diri mereka pribadi saja, tapi juga lingkungan social di sekitarnya terutama orang-orang terdekat seperti keluarga. Penggunaan mesin yang semakin canggih dan dalam skala yang berlebihan juga dapat menimbulkan rasa malas dan membuat para pekerja ini justru menjadi budak dari mesin.

Adapula klasifikasi dari dampak-dampak negatif yang menimbulkan masalah sosial sebagai dampak dari industrialisasi yang dikemukakan oleh Johnson (1984:261) yang disingkat menjadi 5A, yaitu:

1. Alienation: perasaan keterasingan dari diri, keluarga dan kelompok sosial yang dapat menimbulkan apatis, marah, dan kecemasan.

2. Alcoholism atau Addiction: ketergantungan terhadap alkohol, obatobat terlarang atau rokok yang dapat menurunkan produktifitas, merusak kesehatan pisik dan psikis, dan kehidupan sosial seseorang.

3. Absenteeism: kemangkiran kerja atau perilaku membolos kerja dikarenakan rendahnya motivasi pekerja, perasaanperasaan malas, tidak berguna, tidak merasa memiliki perusahaan, atau sakit pisik dan psikis lainnya.

4. Accidents: kecelakaan kerja yang diakibatkan oleh menurunnya konsentrasi pekerja atau oleh lemahnya sistem keselamatan dan kesehatan lingkungan kerja.

5. Abuse: bentukbentuk perlakuan salah terhadap anakanak atau pasangan dalam keluarga (istri/suami), seperti memukul dan menghardik secara berlebihan yang ditimbulkan oleh frustrasi, kebosanan dan kelelahan di tempat pekerjaannya.

Beberapa permasalahan sosial lainnya yang terkait dengan industrialisasi adalah: diskriminasi di tempat kerja atau tindakantindakan tidak adil terhadap wanita, kaum minoritas, imigran, remaja, pensiunan, dan para penyandang cacat. Beberapa industri dan perusahaan juga kerap menimbulkan dampak negatif terhadap masyarakat di sekitarnya, seperti polusi (udara, air, suara) dan kerusakankeusakan pisik dan psikis bagi para pekerjanya. Para pekerja social industri dapat membantu dunia industri untuk mengidentifikasi dan mengatasi berbagai biaya sosial (social costs) yang ditimbulkan oleh perusahaan.

Di Indonesia saat ini para buruh sedang marak-maraknya menuntut kenaikan upah, terlebih lagi dengan adanya kenaikan harga BBM yang mempengaruhi harga seluruh kebutuhan pokok dan juga tarif transportasi umum. Hal tersebut terasa miris, karena disaat para buruh di negara lain khususnya negara-negara di ASEAN sedang mempersiapkan diri untuk menyambut AFTA dan MEA di tahun 2015 yang tinggal menghitung hari, buruh di Indonesia malah sibuk berdemonstrasi, menuntut pemerintah untuk menaikan upahnya. Padahal keterampilan jauh lebih penting dan akan terus bermanfaat daripada kenaikan upah yang tidak seberapa dan tidak akan pernah cukup untuk menutupi kebutuhan. Hal tersebutlah yang perlu disampaikan agar dipahami oleh para buruh di Indonesia, agar mata mereka terbuka, bahwa kesejahteraan tidak akan terwujud jika hanya bermodal materi. Hal-hal tersebut tentunya dapat diupayakan agar tersampaikan pada para buruh oleh Pekerja 
Sosial industri, karena memang itulah salah satu ranah dari intervensi yang dapat dilakukan oleh seorang Pekerja Sosial industry khususnya di Indonesia.

Di sisi lain, terlepas dari masalah mekanisasi dan otomatiasasi, fenomena dari industrialisasi juga menyebabkan jam kerja yang tak kenal waktu. Sebagai contoh, pekerja yang bekerja pada perusahaan yang bergerak di bidang keuangan seperti bankir, menghabiskan kurang lebih 80 jam setiap minggunya untuk bekerja. Sedangkan menurut pasal 77 ayat 1, UU No.13/2003 mewajibkan setiap pengusaha untuk melaksanakan ketentuan jam kerja. Ketentuan jam kerja ini telah diatur dalam dua sistem seperti yang telas disebutkan diatas yaitu:

a. 7 jam kerja dalam 1 hari atau 40 jam kerja dalam 1 minggu untuk 6 hari kerja dalam 1 minggu; atau

b. 8 jam kerja dalam 1 hari atau 40 jam kerja dalam 1 minggu untuk 5 hari kerja dalam 1 minggu.

Waktu 80 jam kerja yang biasanya sudah termasuk waktu lembur tersebut terlihat jauh selisihnya dengan jam kerja yang ada dalam Undang-undang. Namun waktu kerja yang begitu pada tersebut tidak bisa dihindari karena merupakan tuntutan pekerjaan dan sudah menjadi resiko bagi mereka yang berkecimpung dalam dunia industry perbankan. Salah satu contoh padatnya jam kerja ini, membuktikan bahwa Pekerja Sosial industri memang dibutuhkan dalam rangka memanusiawikan dunia kerja.

\section{Peran Pekerja Sosial Industri}

Pekerjaan Sosial Industri (PSI) dapat didefinisikan sebagai lapangan praktik Pekerjaan Sosial yang secara khusus menangani kebutuhan-kebutuhan kemanusiaan dan sosial di dunia kerja melalui berbagai intervensi dan penerapan metoda pertolongan yang bertujuan untuk memelihara adaptasi optimal antara individu dan lingkungannya, terutama lingkungan kerja. Dalam konteks ini, PSI menangani beragam kebutuhan individu dan keluarga, relasi dalam perusahaan, serta relasi lain yang lebih luas antara tempat kerja dan masyarakat yang dikenal dengan istilah tanggungjawab sosial perusahaan atau Corporate Social Responsibility (CSR). (Suharto, 2006; dalam Suharto 2009)

Pekerja Sosial sebagai agen perubahan yang bertugas mewujudkan keberfungsian sosial masyarakat agar terciptanya kesejahteraan sosial memiliki peran-peran tersendiri dalam menjalankan praktiknya. Dalam dunia industri, pekerja sosial memiliki tugas serta peranan tersendiri. Bidang tugas Pekerja Sosial yang bekerja dalam dunia industry dijelaskan oleh Johnson (1984:263-264), sebagai berikut:

1. Kebijakan, perencanaan dan administrasi. Bidang ini umumnya tidak melibatkan pelayanan sosial secara langsung. Sebagai contoh, perusahaan tidak melibatkan kebijakan untuk peningkatan karir, pengadministrasian program-program tindakan afirmatif, pengkoordinasian program-program jaminan sosial dan bantuan sosial bagi para pekerja, atau perencanaan kegiatan-kegiatan sosial dalam departemen-departemen perusahaan.

2. Praktik langsung dengan individu, keluarga dan populasi khusus. Tugas Pekerja Sosial dalam bidang ini meliputi intervensi krisis (crisis intervention), asesmen (penggalian) masalahmasalah personal dan pelayanan rujukan, pemberian konseling bagi pecandu alcohol dan obatobatan terlarangm pelayanan dan perawatan sosial bagi anak-anak pekerja dalam perusahaan atau organisasi serikat kerja, dan pemberian konseling bagi pensiunan atau pekerja yang menjelang pension.

3. Praktik yang mengkombinasikan pelayanan sosial langsung dan perumusan kebijakan sosial bagi perusahaan.

Dengan demikian, dapat disimpulkan bahwa kebutuhan akan Pekerja Sosial industry dalam perusahaan sangatlah luas cakupannya. Tidak hanya sekedar menangani dampak dari pemanfaatan teknologi saja, tapi berbagai aspek seperti dampak dari meningkatnya jumlah karyawan, peran 
Pekerja Sosial untuk menjawab isu pemberhentian karyawan dan pada saat perasaan tidak aman timbul pada pegawai (declining mode), dan juga pada saat terjadi conflict of interest pada karyawan seperti konflik karyawan dengan serikat kerja, dengan masyarakat lokal, dengan pemerintah, maupun dengan lembaga swadaya masyarakat yang berhubungan dengan perusahaan. Semua hal tersebut direalisasikan dalam bentuk pelayanan yang diberikan Pekerja Sosial industry.

\section{Pelayanan Pekerjaan Sosial Industri}

Dalam menjalankan tiga bidang tugas dalam ranah industri, Pekerja Sosial dapat menggunakan dua pendekatan baik mikro maupun makro. Dalam pendekatan mikro, terdapat beberapa pelayanan yang berhubungan dengan masalah yang dihadapi individu dalam perusahaan, seperti dengan konseling dan terapi pada individu. Untuk pendekatan makro, pelayanan yang diberikan kepada kelompok melalui terapi kelompok, serta pelatihan dan pengembangan.

Bentuk pelayanan dari pekerja sosial industry di perusahaan tidak hanya mencakup bagian internal perusahaan saja tapi juga mencakup bagian eksternal dari perusahaan, karena di masa sekarang tidak dapat dipungkiri bahwa kesuksesan lingkungan dari suatu perusahaan sama dengan kesuksesan komersil.

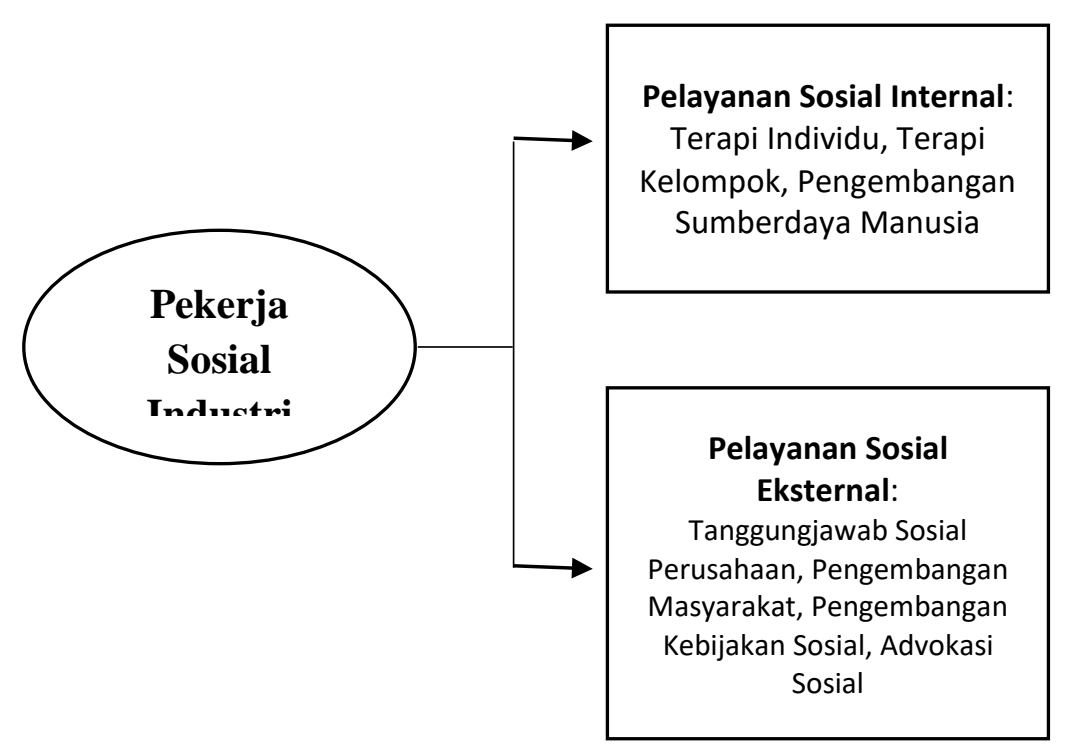

Pelayanan Sosial Internal dan Eksternal Pekerja Sosial Industri (Suharto, 2009:8)

Adapun tipologi model setting Pekerja Sosial Industri (Straussner, 1989:8-13, dalam Suharto, 2009:16) yang merupakan konseptualisasi tentang beragam pelayanan, juga peranan dan keterampilan yang dimiliki Pekerja Sosial Industri, diantaranya adalah:

1. Model pelayanan sosial bagi pegawai (the employee service model)

2. Model pelayanan sosial bagi majikan atau organisasi perusahaan (the employer-work organization service model)

3. Model pelayanan sosial bagi konsumen (the consumer service model)

4. Model tanggungjawab sosial perusahaan (the corporate social responsibility model) atau model investasi sosial perusahaab (the corporate social investment)

5. Model kebijakan public di bidang pekerjaan (work related public policy model).

Dari kelima model dalam tipologi di atas terlihat bahwa peran Pekerja Sosial industry di Indonesia harus memiliki kapasitas yang cukup untuk menangani model-model pelayanan tersebut. Tentunya perlu dibekali keterampilan serta pengetahuan yang sesuai diawali dengan melakukan 
assesmen terhadap budaya yang ada dalam perusahaan agar nantinya memiliki gambaran intervensi seperti apa yang akan diberikan. Dan tentunya yang menjadi catatan penting adalah intervensi yang dilakukan harus secara holistik. Agar hasil dari intervensi menimbulkan perubahan yang maksimal dan berkelanjutan.

\section{Human Resource Development (HRD)}

Human Resource Development (HRD) yang secara harfiah berarti pengembangan sumberdaya manusia, merupakan salah satu bagian dalam perusahaan yang menjadi ranah Pekerja Sosial industry. Dalam HRD Pekerja Sosial industry memiliki tugas untuk melakukan perekrutan, dan hal-hal yang terkait dengan pengembangan sumberdaya manusia yang ada dalam perusahaan untuk meningkatkan kualitas kerja sumberdaya manusia yang dimiliki perusahaan. HRD merupakan bagian penting dalam perusahaan, oleh karena itu peran Pekerja Sosial yang memang memiliki kompetensi untuk menjadi bagian dari HRD sangat dibutuhkan bagi keberlangsungan perusahaan. Salah satu program yang menjadi bagian dari HRD adalah Employee Assistance Programs (EAPs) yang pada praktiknya langsung berhubungan dengan pegawai.

\section{Employee Assistance Programs (EAPs)}

Employee Assistance Programs (EAPs) merupakan salah satu program yang dijalankan Pekerja Sosial industry untuk melakukan asistensi terhadap pegawai yang memberikan pelayanan bagi pekerja baik bersifat penyembuhan (treatment) maupun pelatihan serta pengembangan. EAPs merupakan wujud dari model pelayanan sosial dari pegawai. EAPs pada umumnya diberikan pada pengguna alcohol dan bebas biaya (ditanggung perusahaan melalui asuransi kesehatan, jika menolak beresiko dipecat), walaupun di Indonesia pelayanan seperti ini belum terdengar keberadaannya di perusahaan. Selain itu adapula konseling-konseling mengenai kesulitan emosional ataupun perilaku, keluarga, karier, pendidikan, pelatihan, kredit dan juga mengenai perencaan pensiun pegawai (Zastrow, 2010).

Dalam EAPs, Pekerja Sosial banyak berperan sebagai konselor, linking, broker, serta trainer. Dalam praktiknya pada program EAPs ini, Pekerja Sosial industry banyak dituntut untuk menggunakan pendekatan mikro atau secara individu. Kejelian dalam melakukan assesmen dan menentukan intervensi pun sangat dibutuhkan disini. Seperti halnya pada isu gender yang masih banyak terjadi di perusahaan di Indonesia. Dalam hal ini seorang Pekerja Sosial industry harus jeli dalam melakukan assesmen dan intervensi, bahwa yang seharusnya mendapat intervensi bukanlah perempuan yang menjadi sasaran, tapi human system-nya lah yang membutuhkan intervensi.

Di Indonesia sendiri peran Pekerja Sosial sebagai konselor di perusahaan masih merupakan hal yang tabu bagi masyarakat awam, contoh kecilnya dapat dibuktikan dengan jenis lowongan kerja yang tersedia, sulit sekali menemukan konselor pada perusahaan yang memang khusus ditujukan bagi Pekerja Sosial. Sebagai linking dan broker, Pekerja Sosial industry berperan untuk menghubungkan pegawai yang menjadi klien pada sumber-sumber internal maupun eksternal perusahaan yang mendukung keberfungsian klien dalam perusahaan khususnya, lalu memberikan bimbingan lanjut. Sebagai contoh, mengarahkan tempat penitipan anak pada pegawai yang merupakan seorang ibu dan suaminya pun bekerja. Sebgaai trainer Pekerja Sosial industry harus mampu menyuguhkan baik pelatihan, seminar maupun workshop bagi pegawai untuk meningkatkan kapasitas serta performa kerja pegawai agar dapat memberikan yang terbaik bagi perusahaan. Diantaranya adalah pelatihan dan seminar mengenai time management, relaksasi untuk menghadapi burn out, seminar mengenai positive self talk, problem solving, dan pelatihan serta seminar lainnya.

\section{Corporate Social Responsibility (CSR)}

Menurut Nuryana (2005) secara konseptual, CSR adalah sebuah pendekatan dimana perusahaan mengintegrasikan kepedulian sosial dalam operasi bisnis mereka dan dalam interaksi 
mereka dengan para pemangku kepentingan (stakeholders) berdasarkan prinsip kesukarelaan dan kemitraan. Di Indonesia, keberadaan sudah cukup populer. Terbukti dari telah banyaknya perusahaan yang menerapkan pendekatan CSR dan memiliki program CSR dalam perusahaannya.

Hubungan antara Pekerja Sosial Industri degan CSR muncul karena yang terjadi pada masyarakat industry sehingga menimbulkan fenomena DEAF (Dehumanisasi, Equalisasi, Aquariumisasi, dan Feminisasi) yang dikemukakan oleh Edi Suharto (2006). Berikut ini adalah penjabarannya:

1. Dehumanisasi Industri

Efisiensi dan mekanisasi yang semakin menguat di dunia industri telah menciptakan persoalan-persoalan kemanusiaan baik bagi kalangan buruh di perusahaan, maupun bagi masyarakat di sekitar perusahaan. Tindakan merger dan perampingan perusahaan telah menimbulkan gelombang Pemutusan Hubungan Kerja (PHK) dan pengangguran. Ekspansi dan eksploitasi industri telah melahirkan ketimpangan sosial, polusi dan kerusakan lingkungan yang hebat.

2. Equalisasi Hak-hak Publik

Masyarakat kini semakin sadar akan haknya untuk meminta pertanggungjawaban perusahaan atas berbagai masalah sosial yang seringkali ditimbulkan oleh beroperasinya perusahaan. Kesadaran ini semakin menuntut akuntabilitas (accountability) perusahaan, bukan saja dalam proses produksi, melainkan juga dalam kaitannya dengan kepedulian perusahaan terhadap berbagai dampak sosial yang ditimbulkannya.

3. Aquariumisasi Dunia Industri

Dunia kerja kini semakin transparan dan terbuka laksana akuarium. Perusahaan yang hanya memburu rente ekonomi dan cenderung mengabaikan hokum, prinsip etis dan filantropis tidak akan mendapat dukungan public. Bahkan dalam banyak kasus, masyarakat menuntut agar perusahaan seperti ini ditutup.

4. Feminisasi Dunia Kerja

Semakin banyak wanita yang bekerja menuntut penyesuaian perusahaan, bukan saja terhadap lingkugan internal organisasi, seperti pemberian cuti hamil dan melahirkan, keselamatan dan kesehatan kerja, melainkan juga terhadap timbulnya biaya-biaya sosial, seperti penelantaran anak, kenakalan remaja, akibat berkurangnya atau kehadiran ibu-ibu di rumah dan tentunya di lingkungan masyrakat. Pelayanan sosial seperti perawatan anak (child care), pendirian fasilitas pendidikan dan kesehatan bagi anak-anak, atau pusat-pusat kegiatan olah raga dan rekreasi bagi remaja merupakan sebuah "kompensasi" sosial terhadap isu ini.

Penelitian Public Interest Research and Advocay Center (RIRAC) pada tahun 2001 menunjukkan bahwa dana CSR di Indonesia mencapai lebih dari 115 miliar rupiah dari 180 perusahaan yang dibelanjakan untuk 279 kegiatan sosial. Ditambah lagi dengan keberadaan perusahaan besar di Indonesia yang sudah peduli untuk melakukan CSR, seperti PT Pertamina, Coca Cola, Unilever, Nestle, serta Indocement dan masih banak lagi. Hal ini menunjukan kesadaran perusahaan akan pentingnya menjaga masyarakat serta lingkungan sekitar, jadi tidak hanya mencari kesuksesan ekonomi belaka, tapi juga keberhasilan dalam menjaga keberlangsungan lingkungan serta dalam memberdayakan masyarakat setempat sudah menjadi indicator dari keberhasilan perusahaan.

Seperti yang dikembangkan oleh Archie B. Carrol mengenai hal-hal yang membuat CSR perlu diterapkan kepada masyarakat sekitar perusahaan. Konsep tersebut kemudian dinamakan konsep Piramida Tanggungjawab Sosial Perusahaan (Saidi dan Abidin, 2004; Suharto, 2009:102), yang berisi sebagai berikut:

a. Tanggungjawab ekonomis. Kata kunci: make a profit.

b. Tanggungjawab legal. Kata kunci: obey the law. 
c. Tanggungjawab etis. Kata kunci: be ethical.

d. Tanggungjawab filantropis. be a good citizen .

Dengan tanggungjawab ekonomis sebagai bagian dasar dari piramida maka keuntungan atau profit perusahaan tetaplah menjadi hal utama karena hal tersebut merupakan modal utama suatu perusahaan dapat terus berjalan. Di bagian kedua berisi tentang kewajiban perusaan untuk selalu taat pada hukum yang berlaku, dan menjalankan setiap program berdasarkan hukum yang berlaku. Yang ketiga adalah tanggungjawab etis perusahaan dalam setiap langkah kerjanya. Perusahaan bukan hanya harus taat pada hukum yang berlaku, tapi juga sesuai dengan nilai, norma dan etika yang ada. Yang terakhir, ditingkat teratas terdapat tanggungjawab filantropis dari perusahaan, yakni seputar kedermawanan perusahaan terhadap lingkungngan sekitar dengan cara menyalurkan bantuan baik melalui community development, sponsorship dan program pemberi bantuan bagi masyarakat, maupun bantuan langsung pada korban bencana. Salah satu contohnya adalah program bantuan penyediaan sumber air di daerah yang membutuhkan di Papua yang dilakukan oleh Aqua.

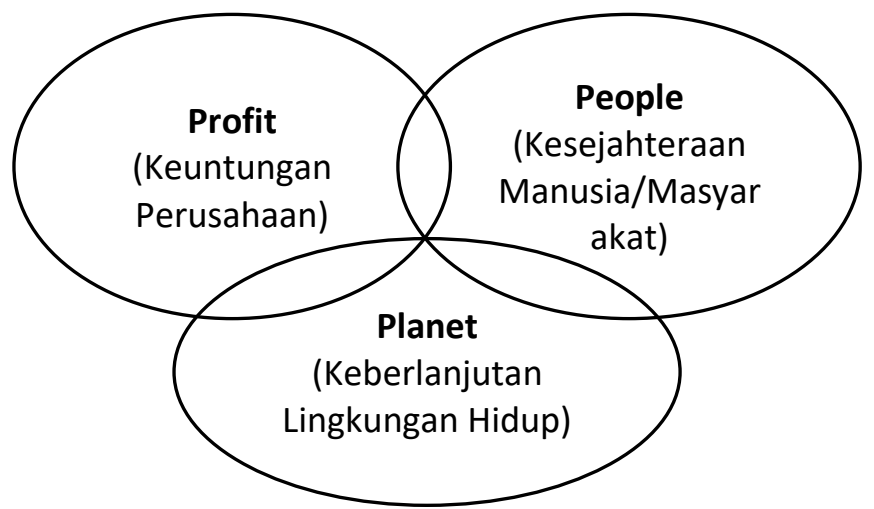

Triple Bottom Lines dalam Corporate Social Responsibility (Suharto, 2009:107)

Untuk lebih dapat memahami konsep piramida milik Archie B. Carol, adapula prinsip dasar CSR atau yang lebih dikenal dengan Triple Bottom Lines yang dikemukakan oleh Elkington, yang disebut 3P, seperti yang terlihat pada gambar di atas, terdiri dari profit, planet dan people. Ketiga hal ini pada akhirnya menimbulkan kesadaran bagi perusahaan bahwa keuntungan dan keberhasilan peruahaan tidak hanya semata-mata dilihat dari sisi keuntungan ekonominya saja, namun juga keberhasilan dalam memberdayakan masyarakat dan menjaga keberlangsungan alam.

\section{Kesehatan dan Keselamatan Kerja (K3)}

Akhir-akhir ini, isu mengenai kesehatan dan keselamatan kerja pekerja sudah bukan merupakan hal yang asing bagi masyarakat Indonesia. Pada bulan Mei tahun 2014 berdasarkan data BPJS Ketenagakerjaan, angka kecelakaan kerja nasional mencapai 8.900 dari bulan Januari hingga bulan April 2014. Melihat tingginya angka kecelakaan kerja yang terjadi serta potensi akan pengaruh terhadap individu sebagai pekerja dan keluarganya, maka perhatian perusahaan akan kesehatan dan keselamatan kerja pekerja merupakan hal yang perlu diutamakan. Kesehatan dan keselamatan kerja pegawai ini diberlakukan bukan hanya pada saat pekerja mengalami kecelakaan, tapi juga sebagai pencegahan agar angka kecelakaan dan ketidaksehatan pekerja dapat diminimalisir bahkan dihindari.

Kesehatan dan keselamatan kerja ini juga tidak hanya seputar individu yang bekerja dalam perusahaan, tapi juga anggota keluarga individu. Dalam praktiknya, Pekerja Sosial industry pada bagian ini harus mampu menyatukan pengetahuan seputar sosial, ekonomi, dan politik dengan keterampilan yang dimiliki seperti pelayanan langsung yang mencakup assesmen terhadap aspek psikososial, menjadi caseworker, dan juga terapi serta pelatihan bagi pekerja seputar kesehatan dan keselamatannya pada saat bekerja. Selain itu, pelayanan sosial yang diberikan Pekerja Sosial industry 
ini juga mencakup advokasi bagi pekerja serta keluarganya yang mengalami kecelakaan kerja dan belum mendapatkan haknya.

\section{Advokasi Sosial dan Kebijakan Sosial}

Advokasi sosial termasuk ke dalam bagian CSR dalam perusahaan. Secara singkat, advokasi sosial merupakan salah satu pelayanan yang dilakukan Pekerja Sosial dalam rangka memberdayakan masyarakat dan juga memberikan bantuan pada klien, dengan cara membantu klien untuk mengakses sumber-sumber yang dibutuhkan serta stakeholder terkait, serta merancang kebijakan dan program terkait kesejahteraan sosial mereka.

Berkaitan dengan advokasi sosial, pelayanan yang dapat pula dilakukan Pekerja Sosial adalah dengan cara turut andil dalam kebijakan sosial. Hasil dari kebijakan sosial yang dapat diterpakan dalam perusahaan mencakup bidang jaminan sosial, pelayanan sosial personal, perumahan, kesehatan, dan juga pendidikan. Berikut adalah proses kebijakan sosial.

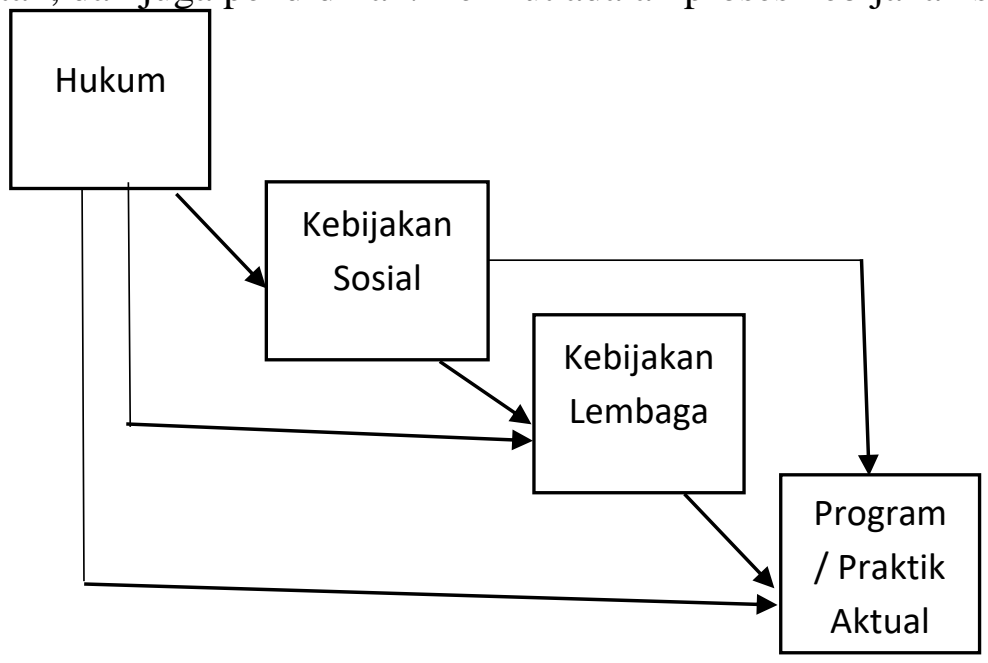

Sumber: Thomson (2004:45; Suharto, 2009)

\section{Penutup}

Pekerja Sosial industry di Indonesia memiliki peran yang penting dalam memanusiawikan dunia industri. Dengan banyaknya permasalahan dalam dunia industry di Indonesia, seperti jumlah angkatan kerja yang besar namun kualitas kerja yang relative rendah, kesehatan dan keselamatan kerja yang belum sepenuhnya diterapkan perusahaan, adanya isu gender, kebijakan yang tidak mendukung, serta hal-hal lain yang mengganggu dan mengahambat kesejahteraan pekerja, membuka lapangan atau bidang garapan bagi Pekerja Sosial industry.

Hanya saja kesadaran perusahaan dan stakeholder terkait yang berada dalam duni industry belum paham betul dan sadar akan kebutuhan Pekerja Sosial industry di Indonesia. Oleh itu diperlukan lebih banyak penyebaran informasi dan juga bukti nyata dari praktik Pekerja Sosial industry.

Begitu pula dengan Pekerja Sosial industry dan lembaga terkait yang memiliki andil dalam eksistensi dari peran Pekerja Sosial industry. Perlu lebih banyak lagi sosialisasi dan penyajian data pasti mengenai Pekerja Sosial, seperti dengan mengesahkan RUU mengenai Pekerja Sosial sebagai payung hukum sehingga posisi Pekerja Sosial di Indonesia menjadi lebih diakui dan jelas bidang intervensinya, khusunya Pekerja Sosial industri.

Lulusan atau mereka yang memiliki dasar pendidikan pekerjaan sosialpun diharapkan memiliki kompetensi yang cukup, diantaranya dengan mengikuti sertifikasi pekerjaan sosial, untuk bekerja dalam sector yang menjadi garapan pekerjaan sosial dan tentunya harus diiringi dengan rasa 
percaya diri dan bangga atas profesi Pekerja Sosial. Karena jika bukan dimulai dari diri sendiri, siapa lagi yang akan memperkenalkan Pekerja Sosial di kancah nasional?

\section{Sumber Buku:}

\section{DAFTAR PUSTAKA}

Johnson, Wayne. 1984. The Social Services: An Introduction. Illinois: F.E. Peacock Publisher. Skidmore, Rex A., Milton G. Thackeray dan William O. Farley (1991). Introduction to Social Work. New Jersey: Prentice-Hall.

Suharto, Edi. 2009. Pekerja Sosial di Dunia Industri: Memperkuat CSR (Corporate Social Responsibility). Bandung: Alfabeta.

Wibhawa, Budhi dkk. 2010. Dasar-Dasar Pekerjaan Sosial. Bandung: Widya Padjadjaran.

\section{Jurnal, Hasil Penelitian, Artikel:}

Kemensos RI. 2013. Sejarah Baru Perkembangan Pekerja Sosial di Indonesia. Melalui < http://dissos.jabarprov.go.id/ > [ 13/12/2014]

Suharto, Edi. (tanpa tahun). Pekerjaan Sosial Industri. Melalui <http://policy.hu/suharto/modul_a/makindo_26.htm $>$ [13/12/2014]

\section{Sumber Lainnya:}

Undang-Undang Nomor 13 Tahun 2003 mengenai Ketenagakerjaan. 